\title{
Paradigma Kritis Dalam Penelitian Wacana
}

\author{
Suharyo \\ Fakultas Ilmu Budaya, Universitas Diponegoro \\ haryo.sastra@gmail.com
}

\begin{abstract}
So far, linguistic research, especially discourse research, is still focused on aspects of the linguistic structure as forming the discourse. Discourse is examined for the existence of cohesiveness and coherence of the discourse. What are the linguistic units that form cohesiveness and cohesiveness both lexical and grammatical coherence. This is different from discourse research using critical discourse paradigms. Critical discourse holds that discourseforming structures are not in a social "vacuum". Because, discourse is basically a (social) action that is loaded with political, economic, power, cultural background etc. To conduct discourse research using critical paradigms, it is necessary to know the research characteristics of critical discourse analiysis, which includes (1) discourse is (social) action, (2) context, (3) historical, (4) power, (5) ideology, and ( 6) (diction) vocabulary basically (a) limits classification, (b) limits the views of a person / group, and (c) marginalizes certain people / groups. Among the available models, the critical discourse analysis model of the van Dijk model is a well-known model in Indonesia.
\end{abstract}

Keywords: discourse research, paradigm, critical discourse

\section{INTISARI}

Selama ini penelitian kebahasaan, khususnya penelitian wacana masih difokuskan pada aspek struktur linguistik sebagai pembentuk wacana tersebut. Wacana dikaji pada ada tidaknya kohesifitas dan kekoherenan wacana tersebut. Apa sajakah satuan-satuan linguistik yang membentuk kohesifitas dan kohorensian baik koherensi leksikal maupun gramatikal. Hal ini, berbeda dengan penelitian wacana dengan menggunakan paradigma wacana kritis. Wacana kritis berpandangan bahwa struktur pembentuk wacana tidak berada pada "ruang hampa" sosial. Sebab, wacana pada dasarnya adalah sebuah tindakan (sosial) yang sarat dengan latar belakang politik, ekonomi, kekuasan, budaya dll. Untuk melakukan penelitian wacana dengan menggunakan paradima kritis perlu mengetahui karakteristik peneltian analiisis wacana kritis, yang meliputi (1) wacana merupakan tindakan (sosial), (2) konteks, (3) historis, (4) kekuasaan, (5) ideologi, dan (6) (diksi) kosakata pada dasarnya (a) membatasi klasifikasi, (b) membatasi pandangan seseorang/kelompok, dan (c) memarginalisasi orang/kelompok tertentu. Di antara sekian model yang ada, model analsisis wacana kritis model van Dijk merupakan model yang cukup dikenal di Indonesia.

Kata kunci: penelitian wacana, paradigma, wacana kritis 


\section{PENDAHULUAN}

Istilah wacana yang sekarang ini sangat dikenal berasal dari kata discourse (bahasa Inggris) dan discursus (bahasa Latin) yang berarti 'lari kian kemari'. Lalu, kini wacana ada yang mengartikan 'komunikasi pikiran dengan kata-kata; ekspresi ide-ide atau gagasan-gagasan; konversasi atau percakapan.' Ismail Marahimin (1994) dalam bukunya yang berjudul "Menulis secara Populer" mengatakan bahwa wacana adalah kemampun untuk maju (dalam pembahasan) menurut urut-urutan yang teratur dan semestinya, dan komunikasi buah pikiran, baik tulisan maupun lisan, yang resmi dan teratur. Sementara Pratikto (1984) menjelaskan bahwa proses berpikir seseorang sangat erat kaitannya dengan ada tidaknya kesatuan dan koherensi dalam tulisan yang disajikannya. Jadi, wacana lebih dilihat dalam perspektif linguistik (semata). Wacana digambarkan untuk menggambarkan sebuah struktur yang luas melebihi batasan-batasan kalimat. Hal ini, berbeda dengan pandangan Mills (via Sobur, 2009) yang menjelaskan bahwa hendaknya ketika menganalisis wacana tidak hanya memerhatikan aspek linguistiknya semata, tetapi juga untuk mengungkap norma-norma atau aturan-aturan bahasa yang implisit, yang berupa simbol-simbol. Apalagi pada era globalisasi seperti sekarang ini.

Pada era globalisasi seperti sekarang ini wujud kekuasaan dan kekerasan mengalami perubahan secara radikal. Menurut Fashri (2007) kekuasaan dan kekerasan dipikirkan sebagai suatu entitas yang terpisah, yaitu bahwa kekuasaan sepertinya tidak bersinggungan dengan kekerasan; dan begitu pun sebaliknya. Lebih lanjut dikatakannya bahwa perwujudan relasi kekuasaan dan kekerasan pada era sekarang ini tidak lagi tampil dalam ruang konkret yang melibatkan aktivitas fisikal. Keduanya beroperasi dalam sebuah ruang representasi yang menjadikan sumber daya simbol sebagai kekuatan abstrak untuk menciptakan kebenaran. Melalui representasilah, sebuah realitas yang sebelumnya tidak dapat dihadirkan bisa direpresentasikan kembali melalui mobilisasi sistem simbol (bahasa).

Mobilisasi simbol yang dilakukan penguasa/kelompok dominan bertujuan mempertahankan kekuasaan (simbolik). Sebab, setiap kekuasaan cenderung untuk dipertahankan, dilestarikan, diproduksi kembali oleh aktor atau insitusi yang memiliki kekuasaan tersebut melalui strategi hegemoni untuk menciptakan ide-ide/simbol-simbol dominan/hegemoni semantik (Gramsci via Fashri, 2007: 13). Melalui hegemoni, ide-ide (wacana) tersebut menentukan struktur koginitif masyarakat. Sebagi contoh, pada masa 
ORLA tercipta hegemoni ide (wacana) neokolonilaisme, imperalisme, dan kapitalisme; masa ORBA dengan demokrasiPancasila, stabilitas nasional, dan anti-PKI-nya;dan Orde Reformasi dengan kebebasan, transparansi, demokrasi dan antiterorisme (lihat George Orwell via Ibrahim, 2006: 50; Badara, 2012; Eriyanto, 2011). Jadi, bahasa dalam hal ini tidak hanya semata-mata dilihat sebagai sebuah struktur, tetapi sebagai praktik sosial. Sebagai praktik sosial, bahasa tidak bisa direduksi pada tataran analisis linguistik murni semata, tetapi harus dilihat dalam konteks dan interaksi sosialnya. Dalam konteks ini, praktik sosial tersebut; wacana/teks tidak hanya sekadar rangkaian kalimat yang terdiri atas subjek, predikat, objek, dan fungsi lainnya; tetapi di balik wacana/teks tersebut "tersembunyi" ideologi tertentu (Santoso, 2009). Wacana menurut Badara (2012: 5) bukanlah hanya sekadar kumpulan kalimat, tetapi memuat world-view. Di balik berita juga sesungguhnya "tersembunyi" ideologi (pembicara/penulis). Sebab, berita di media massa (baca: surat kabar) merupakan representasi simbolis dan nilai suatu masyarakat (Badara, 2012: 5).

Jadi, jika selama ini wacana dikaji dari aspek linguistiknya semata. Tulisan ini akan memaparkan bagaimana pandangan wacana kritis dalam memperlakukan wacana/teks. Untuk selanjutnya, dipaparkan aspek-aspek apa saja yang terkait dengan analisis wacana kritis.

\section{Konsep Wacana dalam Paradigma Wacana Kritis}

Foucault (via Eriyanto, 2011) mengatakan bahwa wacana hendaknya tidak dipahami sebagai rangkaian kata atau proposisi dalam teks semata, tetapi merupakan sesuatu yang memproduksi yang lain. Wacana dapat memuat secara sistematis suatu ide, konsep, dan pandangan hidup yang dibentuk dalam suatu konteks tertentu sehingga mempengaruhi cara berpikir dan bertindak seseorang/kelompok tertentu. Dari pandangan ini pulalah muncul tesis Foucault bahwa terdapat hubungan antara pengetahuan dan kekuasaan. Kuasa oleh Foucault tidak dimaknai dalam term "kepemilikan", tetapi dalam praktik. Bagi Foucault kekuasaan selalu teraktualisasikan lewat pengetahuan dan pengetahuan selalu mempunyai efek kuasa. Penyelengara kekuasaan (pemerintah) selalu memproduksi pengetahuan sebagai basis dari kekuasaannya. Pengetahuan bukan merupakan pengungkapan yang samar-samar dari relasi kuasa, tetapi pengetahuan berada di dalam relasi-relasi itu sendiri. Oleh karena itulah, wacana (tertentu) menghasilkan pengetahuan dan kebenaran (tertentu) yang menimbulkan efek kuasa. Kebenaran bagi Foucault tidak datang dari langit, tetapi ia diproduksi oleh penguasa/kelompok dominan yang didiseminasikan lewat wacana yang dibentuknya. Dengan 
demikian,sekarang ini masyarakat tidak dikontrol lewat kekuasaan yang bersifat fisik, tetapi lewat wacana. Misal, wacana yang berupa prosedur, aturan, tata cara, surat edaran, AD/ART, danbahkan berita di media massa.

\section{Produksi Wacana}

Studi analsisis wacana bukan sekadar mengenai pernyataan (kumpulan kalimat), melainkan juga mengkaji struktur dan tata aturan dari wacana dalam mengekpresikan realitas. Realitas bagi Foucault (via Eriyanto, 2011) merupakan seperangkat konsep/"struktur" yang dibentuk melalui wacana. Wacana membatasi bidang pandangan kita. Contoh tentang realitas/objek PKI. Pada masa ORLA merupakan partai yang diakui Pemerintah bahkan termasuk lima partai terbesar pada saat itu; tetapi pada masa ORBA, PKI merupakan partai terlarang. Hal ini menunjukkan bahwa wacana pada hakikatnya adalah sebuah produk yang dihasilkan oleh masyarakat yang dominan dan masyarakat yang marginal.

\section{Karakteristik Analisis Wacana Kritis}

Dalam analisis wacana kritis, wacana tidak dipahami semata sebagai studi bahasa. Analisis wacana memang menggunakan bahasa dalam teks untuk dianalisis, tetapi bahasa yang dianalisis di sini agak berbeda dengan studi bahasa dalam pengertian linguistik tradisional. Bahasa dianalisis bukan dengan menggambarkan semata dari aspek kebahasaan, tetapi juga menghubungkan dengan konteks. Konteks di sini berarti bahasa itu dipakai untuk tujuan dan praktik tertentu, termasuk di dalamnya praktik kekuasaan.

Menurut Fairclough dan Wodak (via Eriyanto, 2011) analisis wacana kritis melihat wacana-pemakaian bahasa dalam tuturan dan tulisan-sebagai bentuk dari praktik sosial. Menggambarkan wacana sebagai praktik sosial menyebabkan sebuah hubungan dialektis di antara peristiwa diskursif tertentu dengan situasi, institusi, dan struktur sosial yang membentuknya.

Berikut disajikan karakteristik analisis wacana kritis yang dipandang penting.

\section{Tindakan}

Prinsip pertama, wacana dipahami sebagai sebuah tindakan (action). Dengan pemahaman semacam ini mengasosiasikan wacana sebagai bentuk interaksi. Implikasinya, ada beberapa konsekuensi bagaimana wacana harus dipandang. Pertama, wacana dipandang sebagai sesuatu yang bertujuan, apakah untuk mempengaruhi, mendebat, membujuk, menyanggah, bereaksi, dan sebagainya. Seseorang dalam berbicara atau menulis mempunyai maksud tertentu, baik besar maupun kecil. Kedua, wacana dipahami sebagai sesuatu yang diekspresikan secara 
sadar, terkontrol, bukan sesuatu yang di luar kendali atau diekspresikan di luar kesadaran (Eriyanto, 2011). Lebih jauh dikemukakan bahwa bahasa adalah sarana manusia untuk memahami dan mengklasifikasi realitas. Karenanya, melalui tindak penamaan, terutama yang diakui secara luas, seseorang (yang berkuasa) bisa menstrukturkan persepsi terhadap realitas dengan cara tertentu, dan dengan demikian mempertahankan atau mengubah realitas itu sendiri. Semua agen sosial, sejauh dimungkinkan oleh keadaannya, selalu berusaha menggapai kuasa dengan cara menciptakan realitas melalui kata-kata. Contoh dalam kehidupan sehari-hari seperti gosip, hinaan, ejekan, kritik, bantahan, dan pujian, debat, pertengkaran, dan perseteruan. Semua masalah tersebut, misalnya sering kita baca/saksikandi media massa, media elektronika, dan di jejaring sosial (lihat kasus Farhat Abbas dan Ahmad Dhani, kampanye hitam, kampanye negatif pilihan presiden, misalnya).

Hal di atas menunjukkan bahwa kosakata merupakan alat dalam pertarungan wacana. Dalam suatu pemberitaan, misalnya, setiap pihak memiliki versi / pendapat sendiri-sendiri atas suatu masalah. Mereka memiilki klaim kebenaran dasar pembenar dan penjelas mengenai suatu masalah. Bahkan mereka bukan hanya mempunyai versi yang berbeda, tetapi juga berusaha agar versinya/tindakannya yang dianggap benar dan lebih menentukan dalam mempengaruhi opini publik ( Eriyanto, 2011: 140).

\section{Konteks}

Analisis wacana kritis mempertimbangkan konteks wacana, seperti: latar, situasi, peristiwa, dan kondisi. Wacana di sini dipandang, diproduksi, dimengerti, dan dianalisis pada suatu konteks tertentu. Mengikuti Guy Cook (via Eriyanto, 2011), analisis wacana juga memeriksa konteks dari komunikasi: siapa yang mengkomunikasikan dengan siapa dan mengapa; dalam jenis khalayak dan situasi apa; melalui apa; bagaimana perbedaan tipe dari perkembangan komunikasi; dan hubungan untuk setiap masing-masing pihak. Titik tolak analisis wacana di sini, bahasa tidak bisa dipahami sebagai mekanisme internal dari linguistik semata dan bukan suatu objek yang diisolasi dalam ruang tertutup. Bahasa di sini dipahami dalam konteks secara keseluruhan. Selanjutnya, ada tiga hal yang sentral dalam pengertian wacana, yaitu teks, konteks, dan wacana. Teks adalah semua bentuk bahasa, bukan hanya kata-kata yang tercetak di lembar kertas, tetapi juga semua jenis ekspresi komunikasi, ucapan, musik, gambar, efek suara, citra, dan sebagainya. Konteks memasukkan semua situasi dan hal yang berada di luar teks dan mempengaruhi pemakaian bahasa, seperti partisipan dalam bahasa, 
situasi tempat teks tersebut diproduksi, fungsi yang dimaksudkan, dan sebagainya. Jadi, wacana di sini dimaknai sebagai teks dan konteks bersama-sama.

\section{Historis}

Menempatkan wacana dalam konteks sosial tertentu, berarti wacana diproduksi dalam konteks tertentu dan tidak dapat dimengerti tanpa menyertakan konteks yang menyertainya. Salah satu aspek penting untuk bisa mengerti teks adalah dengan menempatkan wacana itu dalam konteks historis tertentu. Misalnya, kita melakukan analisis wacana teks selebaran mahasiswa menentang Soeharto. Pemahaman mengenai wacana teks ini hanya akan diperoleh kalau kita bisa memberikan konteks historis tempat teks itu diciptakan. Bagaimana situasi sosial politik pada saat itu. Oleh karena itu, pada waktu melakukan analisis perlu tinjauan untuk mengerti mengapa wacana yang berkembang atau dikembangkan seperti itu, mengapa bahasa yang dipakai seperti itu, dan seterusnya.

\section{Kekuasaan}

Analisis wacana kritis juga mempertimbangkan elemen kekuasaan (power) dalam analisisnya. Di sini, setiap wacana yang muncul, dalam bentuk teks, percakapan, atau apapun, tidak dipandang sebagai sesuatu yang alamiah, wajar, dan netral; tetapi merupakan bentuk pertarungan kekuasaan. Konsep kekuasaan merupakan salah satu kunci hubungan antara wacana dengan masyarakat. Seperti kekuasaan laki-laki dalam wacana mengenai seksisme, kekuasaan kulit putih terhadap kulit hitam dalam wacana mengenai rasisme, kekuasaan perusahaan berbentuk dominasi pengusaha kelas atas kepada bawahan, dan sebagainya. Kekuasaan itu dalam hubungannya dengan wacana, penting untuk melihat apa yang disebut sebagai kontrol. Satu orang atau kelompok mengontrol orang atau kelompok lain lewat wacana. Kontrol di sini tidaklah harus selalu dalam bentuk fisik dan langsung, tetapi juga kontrol secara mental atau psikis. Bentuk kontrol terhadap wacana tersebut bisa bermacammacam. Bisa berupa kontrol atas konteks, yang secara mudah dapat dilihat dari siapakah yang boleh dan harus berbicara, sementara siapa pula yang hanya bisa mendengar dan mengiyakan.

Selain konteks, kontrol tersebut juga diwujudkan dalam bentuk mengontrol struktur wacana. Seseorang yang mempunyai lebih besar kekuasaan bukan hanya menentukan bagian mana yang perlu ditampilkan dan mana yang tidak, melainkan juga bagaimana ia harus ditampilkan. Ini misalnya dapat dilihat dari penonjolan atau pemakaian kata-kata tertentu. 
Ideologi juga konsep yang sentral dalam analisis wacana yang bersifat kritis. Hal ini karena teks, percakapan, dan lainnya adalah bentuk dari praktik ideologi atau pencerminan dari ideologi tertentu. Teori-teori klasik tentang ideologi di antaranya mengatakan bahwa ideologi dibangun oleh kelompok yang dominan dengan tujuan untuk mereproduksi dan melegitimasi dominasi mereka. Salah satu strategi utamanya adalah dengan membuat kesadaran kepada khalayak bahwa dominasi itu diterima secara taken for granted.

\section{Kosakata dalam Konteks Analisis Wacana Kritis}

Berikut ini dipaparkan pentingnya kosakata dalam pandangan analisis wacana kritis yang dikutip dari Eriyanto (2011).

\section{Kosakata}

Bahasa dilihat oleh Roger Fowler, dkk. sebagai sistem klasifikasi. Bahasa menggambarkan bagaimana realitas dunia dilihat, memberi kemungkinan seseorang untuk mengontrol dan mengatur pengalaman pada realitas sosial. Akan tetapi, sistem klasifikasi ini berbeda-beda antara seseorang atau satu kelompok dengan kelompok lain. Bahkan Fowler dkk.(via Eriyanto, 2011) melihat bagaimana pengalaman dan politik yang berbeda itu dapat dilihat dari bahasa yang dipakai, yang menggambarkan bagaimana pertarungan sosial terjadi. Arti penting klasifikasi ini dapat dilihat dari bagaimana sebuah peristiwa yang sama dapat dinarasikan dengan bahasa yang berbeda (misal, kasus Obor Rakyat).

\section{Kosakata: Membuat Klasifikasi}

Bahasa pada dasarnya selalu menyediakan klasifikasi. Realitas tertentu dikategorikan sebagai ini, dan akhirnya dibedakan dengan realitas yang lain. Klasifikasi terjadi karena realitas begitu kompleksnya, sehingga orang kemudian membuat penyederhanaan dan abstraksi dari realitas tersebut. Realitas tersebut bukan hanya bisa dikenali, pada akhirnya juga berusaha dibedakan dengan yang lain. Klasifikasi menyediakan arena untuk mengontrol informasi dan pengalaman. Sebut, misalnya, tindakan pasukan Interfet ketika berada di Timor Timur yang memborgol, menodong, dan menggeledah penduduk Timor Timur yang dicurigai sebagai milisi. Tindakan itu dapat dikatakan sebagai "intervensi" (campur tangan pihak asing dalam menangani kerusuhan di Indonesia), dapat juga dikatakan sebagai "menjalankan tugas (apa yang dilakukan oleh Interfet tersebut sesuai dengan misinya untuk menangani sumber kekacauan di Timor Timur. 


\section{Kosakata : Membatasi Pandangan}

Menurut Fowler dkk. (via Eriyanto, 2011), bahasa pada dasarnya bersifat membatasi-kita diajak berpikir untuk memahami seperti itu, bukan yang lain. Klasifikasi menyediakan arena untuk mengontrol informasi dan pengalaman. Kosakata berpengaruh terhadap bagaimana kita memahami dan memaknai suatu peristiwa.

Untuk melihat bagaimana kosakata mempengaruhi pandangan kita tersebut, dapat dilihat kasus konkret pemberitaan media atas kasus Tobelo, Galela, dan Jailolo (Maluku), seperti tampak pada bagan berikut.

\begin{tabular}{|l|l|}
\hline Kosakata Perang & Kosakata Penghalusan \\
\hline $\begin{array}{l}\text { Perang, pembunuhan, pembantaian, } \\
\text { pembasmian, pertempuran, } \\
\text { pembunihangusan, pembersihan }\end{array}$ & Tregedi, insiden, kasus, masalah \\
\hline $\begin{array}{l}\text { Perang antara Islam-Kristen, pertempuran } \\
\text { laskar Islam dan Kristen, pembantaian } \\
\text { pasukan Kristen terhadap mujahidin Islam }\end{array}$ & Kerusuhan berbau SARA, konflik berbau \\
\hline
\end{tabular}

\section{Kosakata : Pertarungan Wacana}

Bahasa merupakan salah satu bentuk simbolik. Peranan bahasa dalam kehidupan sosial sangat penting. Seperti pada era rezim ORBA Soeharto, misalnya, juga memanfaatkkan bahasa untuk mempertahankan kekuasannya. Bahasa merupakan "tempat" bertemunya berbagai kepentingan kelompok manusia. Dalam hal ini, bahasa dapat dipandang sebagai 'arena politik'/arena pertarungan yaitu tempat bertemunya berbagai kepentingan, sebagai arena bertarung yang tujuan akhirnya adalah untuk saling mempengaruhi, saling mendominasi, hegemoni atau hegemoni tandingan, menguasai/melawan oleh satu kelompok/orang yang satu terhadap kelompok/orang lain. Berkaitan dengan kehidupan politik dan atau kekuasaan, bahasa menjadi penting terutama karena bahasa dapat digunakan sebagai instrumen pertarungan politik, baik untuk menaklukkan, melawan, atau untuk mempertahankan kekuasaan.

Menurut Bourdieu, bahasa bukan hanya sebagai instrumen komunikasi, lebih dari itu ia merupakan bagian dari suatu instrumen yang dengannya manusia mengaktualisasikan harapan-harapan, rencana-rencana, dan ambisi-ambisi. Bahasa politik adalah praktik 
kekuasaan yang oleh kelompok dominan digunakan untuk mengontrol kelompok marginal (Noorsalim, 2004).

Kosakata juga haruslah dipahami dalam konteks pertarungan wacana. Dalam suatu pemberitaan, setiap pihak mempunyai versi atau pendapat sendiri-sendiri atas suatu masalah. Mereka mempunyai klaim kebenaran, dasar pembenar dan penjelas mengenai suatu masalah. Mereka bukan hanya mempunyai versi yang berbeda, tetapi juga berusaha agar versinya yang dianggap paling benar dan lebih menentukan dalam mempengaruhi opini publik. Dalam upaya memenangkan penerimaan publik tersebut, masing-masing pihak menggunakan kosakata sendiri dan berusaha memaksakan agar kosakata itulah yang lebih diterima oleh publik, seperti dicontohkan berikut ini (Eriyanto, 2011).

\begin{tabular}{|c|c|c|}
\hline PERISTIWA & VERSI MILITER & VERSI GAM \\
\hline Kreung Geukuh & $\begin{array}{l}\text { Militer terpaksa melakukan } \\
\text { penembakan karena massa } \\
\text { yang telah diprovokasi } \\
\text { GAM hendak menyerang } \\
\text { Detasemen Rudal } 001 . \\
\text { Akibat bentrok antara } \\
\text { massa dan militer, } 31 \\
\text { orang tewas. }\end{array}$ & $\begin{array}{l}\text { Tidak ada kontak senjata } \\
\text { dalam peristiwa tersebut. } \\
\text { Militer secara membabi } \\
\text { buta melakukan } \\
\text { penembakan kepada } \\
\text { massa. Akibatnya, } 31 \\
\text { masyarakat tewas. }\end{array}$ \\
\hline Pulo Rungkem & $\begin{array}{l}\text { Kelompok tak dikenal } \\
\text { yang diidentifiaksi sebagai } \\
\text { GAM, secara membabi } \\
\text { buta menyerang dan } \\
\text { melemparkan granat ke } \\
\text { detasemen Rudal } 001\end{array}$ & $\begin{array}{l}\text { Pelemparan gramat itu } \\
\text { dilakukan sendiri oleh } \\
\text { militer untuk mengalihkan } \\
\text { perhatian masyarakat dari } \\
\text { kasus kreung Geukuh. } \\
\text { Terbukti tidak ada } \\
\text { kerusakan serius. }\end{array}$ \\
\hline
\end{tabular}

\section{Kosakata : Memarginalisasi}

Roger Fowler dkk.( via Eriyanto, 2011) menjelaskan bahwa pilihan linguistik tertentu—kata, kalimat, proposisi - membawa nilai ideologis tertentu. Kata dipandang bukan sebagai sesuatu 
yang netral, tetapi membawa implikasi ideologis tertentu. Di sini, pemakaian kata, kalimat, susunan, dan bentuk kalimat tertentu, proposisi, tidak dipandang semata sebagai persoalan teknis tata bahasa atau linguistik, tetapi ekspresi dari ideologi: upaya untuk membentuk pendapat umum, meneguhkan, dan membenarkan pihak sendiri dan mengucilkan pihak lain. Pemakaian bahasa dipandang tidak netral karena membawa implikasi ideologis tertentu. Teks memproduksi "posisi pembacaan" untuk khalayak, dalam arti menyediakan perspektif bagaimana suatu teks melibatkan juga hubungan transaksional dengan pembaca. Contoh berikut dimaksudkan untuk memperjelas.

\begin{tabular}{|c|c|c|c|c|}
\hline $\begin{array}{l}\text { Aktor } \\
\text { (Korban) }\end{array}$ & $\begin{array}{l}\text { Keterangan } \\
\text { Aktor } \\
\text { (Korban) }\end{array}$ & Peristiwa & $\begin{array}{l}\text { Aktor } \\
\text { (Pelaku) }\end{array}$ & $\begin{array}{l}\text { Keterangan } \\
\text { Aktor } \\
\text { (Pelaku) }\end{array}$ \\
\hline Gadis & Cantik & Diperkosa & Pemuda & Pengangguran \\
\hline $\begin{array}{l}\text { Seorang } \\
\text { wanita }\end{array}$ & $\begin{array}{l}\text { Yang } \\
\text { bekerja di } \\
\text { bar }\end{array}$ & Digagahi & Pemuda & $\begin{array}{l}\text { yang sedang } \\
\text { mabuk }\end{array}$ \\
\hline $\begin{array}{l}\text { Gadis } \\
\text { kecil }\end{array}$ & $\begin{array}{l}\text { Yang masih } \\
\text { ingusan }\end{array}$ & Diperawani & Pemuda & $\begin{array}{l}\text { Dari keluarga } \\
\text { broken home }\end{array}$ \\
\hline $\begin{array}{l}\text { Gadis } \\
\text { SMA }\end{array}$ & $\begin{array}{l}\text { Yang sering } \\
\text { keluar } \\
\text { malam }\end{array}$ & Diperawani & $\begin{array}{l}\text { Laki- } \\
\text { laki }\end{array}$ & Tak dikenal \\
\hline $\begin{array}{l}\text { Seorang } \\
\text { anak }\end{array}$ & $\begin{array}{l}\text { Yang } \\
\text { montok }\end{array}$ & Disetubuhi & $\begin{array}{l}\text { Ayahnya } \\
\text { sendiri }\end{array}$ & $\begin{array}{l}\text { Yang baru } \\
\text { bercerai }\end{array}$ \\
\hline
\end{tabular}

\section{Model Analisis Wacana Kritis Teun A. Van Dijk}

Dari sekian banyak analisis wacana yang diperkenalkan dan dikembangkan oleh beberapa ahli, model Van Dijk merupakan model yang paling banyak dipakai (Eriyanto, 2011). Gagasan pokok model Van Dijk terdiri atas beberapa elemen, yaitu (a) teks yang terdiri atas tematik, skematik, latar, detil, maksud, koherensi, bentuk kalimat, kata ganti, dan leksikon; (b) kognisi sosial; (c) analisis sosial yang terdiri dari atas praktik kekuasaan dan akses mempengaruhi wacana; dan (d) kerangka analisis yang terbagi menjadi struktur yang terdiri 
atas teks, kognisi sosial, dan analisis sosial; dan metode yang meliputi linguistik kritis, wawancara mendalam, studi pustaka, penelusuran sejarah.

\section{SIMPULAN}

Dari uraian ringkas di atas, dapat dikemukakan bahwa (a) analisis wacana kritis dapat dijadikan sebagai alternatif dalam melakukan penelitian kebahasaan, khususnya penelitian wacana agar wacana tidak hanya diteliti dari segi struktur pembangun wacananya saja. Analisis wacana kritis menawarkan dari dimensi lain dari struktur pembangun wacana. Dimensi yang dimaksud adalah (a) paradigma yang berbeda dengan analisis wacana selama ini, (b) wacana memiliki karakter, seperti (1) wacana merupakan tindakan (sosial), (2) konteks, (3) historis, (4) kekuasaan, (5) ideologi, dan (6) (diksi) kosakata pada dasarnya (a) membatasi klasifikasi, (b) membatasi pandangan seseorang/kelompok, dan (c) memarginalisasi orang/kelompok tertentu. Di antara sekian model, model analsisis van Dijk merupakan model yang cukup dikenal di Indonesia. Selamat mencoba.

\section{DAFTAR PUSTAKA}

Badara,Aris.2012. Analisis Wacana: Teori, Metode, dan Penerapannya pada Wacana Media. Eriyanto. 2011. Analisis Wacana : Pengantar Analisis Teks Media. Yogyakarta: LKIS.

Fashri, Fauzi.2007. Penyingkapan Kuasa Simbol. Yogyakarta: JUXTAPOSE.

Ismail. 2013. Ironi dan Sarkasme Bahasa Politik Media. Yogyakarta: Pustaka Pelajar.

Latif, Yudidan Idi Subandi Ibrahim. 1998. BahasadanKekuasaan. Jakarta: Mizan.

Marahimin, Ismail.1994. Menulis secara Populer. Jakarta: Pustaka Jaya.

Noorsalim, Mashudi dan Muridan S. Widjojo. 2004. "Bahasa Negara Versus Bahasa Gerakan Mahasiswa (Kajian Semiotik atas Teks-Teks Pidato Presiden Soeharto dan Selebaran Gerakan Mahasiswa)". Jakarta: LIPI Press.

Pratikto, Riyono. 1984.Kreatif Menulis Feature. Bandung: Alumni.

Santoso, Anang. 2009. Bahasa Perempuan.Jakarta: BumiAksara.

Sobur, Alex. 2009. Analisis Teks Media. Bandung: Remaja Rosdakarya. 